\title{
4 \\ Unlocking Land Markets
and Infrastructure Provision
}

\subsection{Introduction}

Land, along with the provision of bulk infrastructure, is central to any discussion on housing development in Africa. As the continent rapidly urbanizes and its population continues to grow, demand for urban and peri-urban land is increasing. This strong demand, fueled in part by the rising income of urban households, has translated to high land sales and rental values. In most African cities, the high cost of urban housing is often due to several issues including inadequate land governance policies that encourage speculative acquisitions, poor urban planning that generates urban sprawl, and the lack of critical infrastructure that has significantly increased the cost of serviced land. Land servicing costs adds to the housing development costs. As a consequence, the available serviced land is limited and out of reach for the majority.

Moreover, high land prices are, in most cases, the consequence of inadequate land policies that result in inefficiencies in the process of making land available for housing development. It is noted that high land prices, weak land markets, and inadequate land administration processes have been the main drivers of informal land market developments in many 
countries across the continent. As a result, the proliferation of informal settlements is a common feature in most large African cities. Today, over 60 percent of urban households in sub-Saharan Africa, consisting mainly of low- and middle-income families, live in informal settlements, compared with about 13 percent in North Africa (UN-Habitat 2010).

In sum, multiple tenure regimes, costly and rigid land administrative procedures, and inefficiencies induced by the political economy of land policies - the usual problems that bedevil formal land markets in Africaare to blame for the continent's dysfunctional land market. Overall, it is important to note that it is the weak governance in many countries that continues to breed corruption, inefficiency, and speculation in land markets. As a result, most African urban households cannot afford to access formally titled land and intrinsically formal housing.

Moreover, much of Africa's urban expansion is occurring through the unplanned and low-density consumption of rural land. Long-standing cultural preferences for freestanding homes and the lack of formal highdensity housing developments have accelerated urban sprawl patterns and the growth of informal settlements across many countries. Africa's growing urban sprawl not only affects rural livelihoods and the future growth patterns of urban settlements, it also entails financial, social, and environmental costs. Most important is the cost of upgrading or putting in place infrastructure and services after the development of peripheral urban settlements, which is excessively prohibitive, especially in informal settlements.

The lack of critical infrastructure further inhibits housing developments in many parts of the continent. Most local and even central governments in Africa today are unable to provide the requisite bulk infrastructure such as roads, electricity, water, sewerage, and road connections to residential properties. As a result, plenty of potentially promising land is not readily available for the housing market.

The result of the above-mentioned constraints is a housing market sharply divided between the haves and the have-nots. At one extreme, a small elite benefit from easy access to land, quality housing, and mortgage products. At the other, the majority of households are stuck in the vast informal sector, reliant on alternative forms of credit, the informal 
land market, and self-provided housing as well as infrastructure and service connections.

This chapter attempts to describe Africa's dysfunctional land markets for housing. It is organized around four important land market phenomena that have major implications on formal sector provision of land and infrastructure for affordable housing in Africa: (1) poor land governance and administration systems; (2) implications of unclear land tenure rights and regime; (3) urban sprawl; and (4) how to increase land supply and the provision of basic infrastructure services.

\subsection{Land Governance and Administration in Africa}

Current land policies and administrative frameworks in Africa have been significantly influenced by various social, economic, and political factors inherited during the colonial era. Under colonialism, titled land was reserved for Europeans and the colonial administration; many Africans could access land only under customary user rights. This is particularly true in former British colonies, wherein Crown land was governed under English law, whereas land occupied by indigenous people was administered under customary law, as in Kenya (Doebele 1983; Wanjala 1990; Musyoka and Musoga 2015).

\subsubsection{Multiple Tenure Regimes and Unclear Land Rights}

The coexistence with the formal system of a customary system of land holding and statutory land rights is prevalent across Africa. Often, government institutions responsible for demarcation of plot boundaries, land registration, record-keeping, and adjudication of land rights are poorly coordinated, with a poor governance system, largely ineffective and lack capacity. This failure has partially contributed to the existence of multiple, parallel, and sometimes even overlapping land tenure regimes across Africa. Although some countries have adopted improvements in 
the security of land rights, for a majority of African governments, land reforms and the enforcement of property rights remain a challenge.

Today, an estimated 10 percent of land in Africa is formally registered to individuals as private (freehold) property, although wide variations exist across regions. In West Africa, for example, only 2-3 percent of land is titled-most of it situated around major cities. In Cameroon, 31 years after the legislation requiring land titling was enacted in 1974 , less than 2 percent of land or an estimated 125,000 titles have been registered (USAID 2011). Likewise, in Burundi, as in most African countries, less than 1 percent of land is registered. In Uganda and Kenya, less than 15 percent of the country is covered under the land titling and cadastral system (Augustinus and Deininger 2005).

Besides creating optimum conditions for entrenching inequalities and failing to protect vulnerable groups, this dual-tenure system has been primarily used to serve the interests of elites in postcolonial Africa. Although legal frameworks for land titling and property rights have been established in many African countries today, these policies have often failed to achieve an efficient and equitable land market because most reforms have been ad hoc and top-down. Moreover, in most African countries there is a lack of a well-defined and coordinated institutional framework to implement the policies effectively. This is exemplified in the constant wrangling between the Ministry of Lands in Kenya and the National Lands Commission over their mandates and responsibilities.

Nowadays, despite the development of comprehensive land reforms promoting statutory land rights in many countries (Table 4.1), customary tenures remain predominant. Today, a vast majority of land sales and rental transactions take place outside statutory legal systems. In subSaharan Africa, customary or informal land markets account for 30-90 percent of all land transactions (Durand-Lasserve 2003). A study conducted in six African countries-Botswana, Kenya, Lesotho, Nigeria, Uganda, and Zambia - showed that 50-70 percent of land transactions for housing take place in the informal markets (Rakodi and Leduka 2004). In Zambia, for example, about 94 percent of urban land is governed under customary laws, with statutory land accounting for only 6 percent of available urban land (UN-Habitat 2012a). In Uganda and in Ghana, customary tenure covers about 60 percent and 78 percent of the 
Table 4.1 Land reforms in selected African countries

\begin{tabular}{|c|c|}
\hline $\begin{array}{l}\text { Land policy with legal } \\
\text { recognition of } \\
\text { customary land }\end{array}$ & Ghana (1999), Guinea (2001) \\
\hline $\begin{array}{l}\text { Land laws enacted with } \\
\text { formal recognition of } \\
\text { customary or user rights } \\
\text { to land and security of } \\
\text { customary land tenure }\end{array}$ & $\begin{array}{l}\text { Niger (1993), Benin (2007), Burkina Faso (2009), } \\
\text { Côte d'Ivoire (1998), Ethiopia (2005), South Sudan } \\
\text { (2009), Kenya (2012), Tanzania (1999), Angola } \\
\text { (2004), Namibia (2002), Zambia (1995), Botswana } \\
\text { (1968/1993), South Africa (1998), Madagascar } \\
\text { (2005), Mozambique (1998), Uganda (1998), } \\
\text { Rwanda (2005), Malawi (2002) }\end{array}$ \\
\hline $\begin{array}{l}\text { Consultative process to } \\
\text { establish new land laws } \\
\text { with recognition of } \\
\text { customary rights }\end{array}$ & $\begin{array}{l}\text { Gambia (1990), Mali (2009), Senegal (2005), Nigeria } \\
\text { (2009), Lesotho (2008/2009), Sierra Leone (2010), } \\
\text { Guinea-Bissau (1998) }\end{array}$ \\
\hline Land is nationalized & Ethiopia (1975), Mozambique (1975) \\
\hline
\end{tabular}

Source: Amanor (2012); national sources

countries' total areas, respectively (AUC-ECA-AfDB 2012). In South Africa, an estimated 40 percent of available land parcels is still under customary land tenure.

In many parts of the continent, land governance frameworks are weak and are often restricted by the complexity of land systems. Attempts to achieve greater efficiency and equity in land markets have resulted in the nationalization of land for public good in some countries, such as Ethiopia and Mozambique. However, very few governments that have chosen the path of nationalization have achieved equitable and transparent land distribution, particularly for the benefit of poor households and marginalized groups. Our fact-finding field visits revealed that even for those countries where land belongs to the state de jure as stipulated in the country's Constitution (e.g., Côte d'Ivoire), in practice, the existence of a customary land regime in parallel makes the law null and void. There is a de facto dual land regime which complicates the land governance system. Processes for obtaining formal land rights and individual titles remain onerous, expensive, and inefficient for the majority of households. Merging the systems of customary and formal land rights is a major challenge faced by most African governments today. In subsequent sections, we discuss efforts made to strengthen and enforce land rights in Africa while highlighting the impediments induced by the existence of a dual-land tenure regime. 


\subsubsection{Poor Land Administration and Management Systems}

Efficient and effective land management and administration is imperative to sustain affordable housing development. In many countries, urban land management and administration remain heavily centralized, particularly in francophone sub-Saharan Africa relative to anglophone subSaharan African countries. The reluctance to decentralize land management and administration to city governments has hindered the development of effective land markets able to satisfy the large demand of urban land. Moreover, the complex administrative procedures and high centralization of land management breed more corruption in land markets.

Even though some countries have adopted policies to decentralize land management to local governments and streamline the registration procedure, in many countries the process of land titling remains long and arduous, with many steps and documents still required. In Kenya, even government officials acknowledge that for many households the steps to register land are not easy to understand. As a consequence, many Kenyans abandon the land registration process or seek tenure security through informal means such as giving "gifts" to speed up the land titling process. In other countries, the registration process can also be exclusive, as in the urban areas of Cameroon, for example, where land in some parts can be allocated only to indigenous people or "autochtones." As a result, land information systems cover only a small portion of available land in most countries, resulting in unclear ownership rights. This reflects the lack of an adequate land registration system including up-to-date maps and registries that can identify and prove who owns land.

Furthermore, in many countries, land data and registries are still maintained manually due to a lack of capacity to acquire and use modern technologies. As a result, information on registered land and land rights is often inconsistent and difficult to gather. Efforts to put together efficient land information systems have often been hampered by the lack of adequate resources (AUC-ECA-AfDB 2010). Consequently, it is not uncommon for land registries to issue multiple titles to different people 
for the same plot of land. Moreover, inaccuracies in boundary limits are commonplace, resulting in land disputes and conflicts. To ensure precision in land record management, governments will need to adopt modern, computerized land registry and cadaster systems. According to the World Bank's Doing Business 2016 report, economies that have digitized their land registry and property systems have seen a 38 percent reduction in the time required to transfer property since 2011, compared with a drop of just 7 percent in countries that have not. Rwanda provides a good example of how computerization can increase transparency, security, and efficiency in land administration and management. In that country, the time required for transferring property dropped significantly from over a year to just one month following the implementation of a computerized land information system (Box 4.1). However, before digitizing land records, governments need to develop a legal and institutional framework, as well as put in place an appropriate technology system, among other preparations.

\section{Box 4.1 Improving Land Governance in Rwanda}

Before the development of the National Land Policy in 2004 and the enactment of the Organic Land Law in 2005, which determined the use and management of land in Rwanda, there was a juxtaposition of customary tenure and statutory tenure. Most rural land in Rwanda was accessed through inheritance and through leasing under customary tenure arrangements, and most urban land was accessed through purchase and leasing under statutory tenure arrangements. Other methods of acquiring land included government land allocation, borrowing, gift, first clearance, and informal occupation. Within nine years of the law's enactment, the government adopted policies and enacted comprehensive reforms that produced an efficient land administration and management system that guaranteed land tenure security through land registration and titling, among other mechanisms.

The government undertook the following key actions:

- Development of a legal and institutional framework: refinement of land policy, development of secondary legislation, and development of land management organizations at the central and district levels (the Land Centre and Office of the Registrar of Land Titles, Land Commissions at the central and district levels, District Land Offices, and Land Committees at decentralized levels) 
- Development of a national system and program for land tenure regularization: to systematically bring land to first registration and to allow all citizens equal access to the new systems

- Development of low-cost, effective, and simplified land administration system at the national and decentralized levels and operational guidelines: to secure land rights and promote investment through regulated land transactions

- Development of a national land use master plan: for land planning and development control, to ensure rational use of land and effective development as well as environment protection

- Development of a land administration information system: with a digital register as a tool that facilitates land data maintenance and flexibility to accommodate new changes (parcel updates, personal and land rights information) and land transactions, contributing to ease of doing business

By the end of December 2012, all of the estimated 10.3 million parcels had been demarcated, adjudicated, and digitized (100 percent); 10.3 million parcels had been entered in the Land Tenure Regularization Database (LTRSS) with full information on 8.3 million parcels; 7 million leasehold titles had been approved; 7 million leasehold titles had been printed for distribution; and 4 million leasehold titles had been collected by owners. Only 11,840 disputes were registered countrywide.

Future developments in the pipeline are linking the digital land information system to mortgage registration, as well as connecting banks to landowners and linking geographical data to land rights.

Source: Rurawanga (2013).

\subsubsection{Inefficient Regulations and Poor Land Use Policies}

Many countries on the continent have official standards and regulations that are unnecessarily costly and outdated, including unrealistic minimum plot sizes and expensive forms of infrastructure that raise the cost of housing and land development. Although planning standards vary significantly across Africa and within countries, overall there is a trend toward standards that are too high. On average, the minimum plot size for residential property in Africa is $262 \mathrm{~m}^{2}$, ranging from a high of $500 \mathrm{~m}^{2}$ in countries such as Angola, Eritrea, and Guinea-Bissau to a low of $60 \mathrm{~m}^{2}$ in Djibouti and Morocco (Fig. 4.1). High standards, for minimum plot sizes in particular, have a significant effect on housing costs and affordability as plot size can significantly inflate construction costs. 


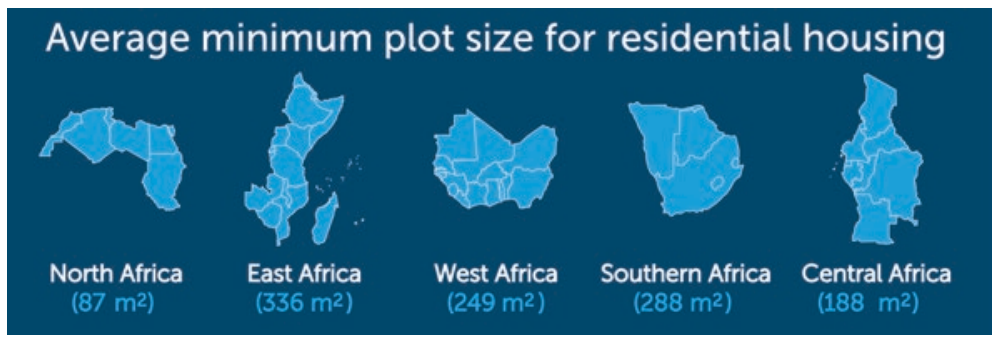

Fig. 4.1 Average residential plot size by region (Source: Author based on CAHF (2015) Annual Survey data)

Many of these standards in Africa are still based on regulations created under colonial rule and were originally instituted for use only within areas of the colonial city that were inhabited by "non-natives" (Satterthwaite 2009). In many cases, urban planning and density restrictions from the colonial era have not been updated to reflect current needs.

In Kenya, for example, land policies and official codes, used as of 2014 were inherited from the colonial government and replicate British building regulations, most of which are not appropriate in today's Kenya. There have been calls on the government to revise these regulations, taking into account the unique characteristics of Kenyan society and housing market dynamics. In neighboring Tanzania, by contrast, minimum plot sizes are unaffordable for most households, particularly the poor, and are too expensive for the government to service owing to prohibitive infrastructure costs (Silva 2015). Using examples from Ghana, South Africa, and Tanzania, Silva concludes that the urban planning concept and the amended regulations adopted in many former British colonies are ill suited for the needs and realities of these countries today. This is largely due to the weak capacity of governments to adopt and implement changes on building standards, their limited financial resources, and the rapid growth rate in urban Africa. There are also emotional and cultural factors that need to be taken into account and which require a mentality change. In the majority of African countries, people have a sentimental relationship with land. In some African communities, the size of land owned reflects someone's wealth and may confer him a certain status in the society. This cultural factor is nonnegligible constraint to the revision of certain standards. 


\subsubsection{Onerous and Complex Land Titling Processes}

It is within the purview of government to establish proper legal frameworks to guide land tenure and transfers. However, in many African countries, the procedure for acquiring and transferring land is fraught with uncertainties. Moreover, the high costs of accessing land and providing secure property rights are major obstacles to the development of land and housing markets. During our fact-finding consultations, housing stakeholders across the continent decried the long, onerous, bureaucratic, and expensive land titling process as a major constraint. While it is reported that formal registration of a property in Africa takes on average slightly less than two months and the associated costs are estimated at 8.1 percent of the property value (Table 4.2), this masks a certain disparity between countries. In 22 African countries today, it takes between 6 and 12 months to register property; in 9 countries, it takes 3-6 months; and in 16 countries, it takes up to 3 months (Table 4.2).

Although onerous titling procedures represent a challenge for all population segments, it is the poor who are disproportionately affected, given that they cannot afford the high administrative costs and typically are less politically connected. In Luanda, Angola's capital city, the waiting period

Table 4.2 Registering property: Inefficient land administration systems in Africa

\begin{tabular}{|c|c|c|c|c|}
\hline & $\begin{array}{l}\text { Procedures } \\
\text { (number) }\end{array}$ & $\begin{array}{l}\text { Time } \\
\text { (days) }\end{array}$ & $\begin{array}{l}\text { Cost (\% of } \\
\text { property } \\
\text { value) }\end{array}$ & $\begin{array}{l}\text { Quality of the land } \\
\text { administration index } \\
(0-30)\end{array}$ \\
\hline Africa & 6.3 & 57.1 & 8.1 & 8.3 \\
\hline North Africa & 6.2 & 47.2 & 4.9 & 9.7 \\
\hline Central Africa & 5.9 & 61.4 & 12.5 & 6.4 \\
\hline East Africa & 7.1 & 44.2 & 6.2 & 9.5 \\
\hline West Africa & 6.2 & 68.8 & 8.7 & 6.9 \\
\hline $\begin{array}{l}\text { Southern } \\
\text { Africa }\end{array}$ & 6.1 & 54.7 & 7.6 & 10.4 \\
\hline $\begin{array}{l}\text { Latin America } \\
\text { and Caribbean }\end{array}$ & 7.0 & 63.0 & 6.1 & 11.5 \\
\hline South Asia & 6.4 & 97.6 & 7.2 & 7.6 \\
\hline $\begin{array}{l}\text { OECD high- } \\
\text { income } \\
\text { countries }\end{array}$ & 4.7 & 21.8 & 4.2 & 22.7 \\
\hline
\end{tabular}

Source: Based on data from World Bank Doing Business 2016 
to obtain full legal occupation rights can last between 15 and 20 years, according to conversations with land experts on the ground. Because of such constraints, over 75 percent of peri-urban residents around Luanda do not have land titles and land rights that are recognized under the law. In Cameroon, an estimated 80 percent of urban land transactions occur in the informal market even though the government streamlined its land registration procedure in 2005. The current process still entails 12 steps, involves 17 organizations, costs 18 percent of the property value, and takes about 93 days. This trend is common across the continent. It highlights the costly and cumbersome land titling process faced by many Africans across the continent.

\subsubsection{Land Administration and Management: A Laissez-Faire Approach of the State}

In the 1960s and 1970s, public land development agencies in several countries had a mission to acquire and develop large land parcels, which were then sold to various social groups, including low- and middleincome families, at below-market prices. This government-controlled land delivery accounted for an estimated 10-40 percent of all land transactions in Africa at the time (Durand-Lasserve 2003). In Cameroon, for instance, agencies such as the Mission d'Aménagement et d'Equipement des Terrains Urbains et Ruraux (the Urban and Rural Lands Development Authority, better known by its French acronym, MAETUR) built tens of thousands of housing units through large-scale programs. MAETUR supplied over 30,000 land plots at its peak in the 1970s.

At the end of the 1970s, several African countries experienced severe macroeconomic difficulties including balance of payments and fiscal deficits, high inflation, and low GDP growth rates. For many analysts, including the IMF and the World Bank, the excessive interventionist role of governments was seen as the main culprit. This triggered the design of massive macroeconomic and structural reform programs, called structural adjustment programs (SAPs). SAPs consisted of the elimination of subsidies, a reduction of government expenditures, the privatization of state-owned enterprises, and the introduction of cost-recovery principle 
with the goal to move service delivery from the public to the private sector. It is against this backdrop that the SAPs were rolled out in a number of African countries during the 1980s-90s. Although its implementation took different forms, the SAPs substantially curtailed budget expenditure in the public sector, which caused the state to gradually lose its capacity to deliver a wide range of services, including the supply of land for housing.

In fact, policy adjustments in the SAPs era led to the gradual withdrawal of the state from the delivery of land for housing. Many state and parastatal land development agencies had to withdraw from land markets as government budgetary support for housing developments dried up; in most cases, the housing developments were canceled. Consequently, many governments adopted a laissez-faire approach to land management, administration, and the regulation of urban housing. This has contributed in the growth of informal settlements and unplanned neighborhoods.

In Côte d'Ivoire, the parastatal called Compte des Terrains Urbains (Urban Land Agency, or CTU), which was established to finance the acquisition and development of land for housing, has not conducted any activity since 1992 owing to the withdrawal of government budgetary support. Since its creation, the CTU has completed just two operations, in 1988 and 1989, resulting in the delivery of a meager 4480 land parcels. During the structural adjustment era, concessionary funding and technical assistance from multilateral agencies and governments dried up, precipitating the collapse of many public land development and servicing agencies, even as the demand for serviced land plots continued to soar. As far as the land market is concerned, the SAPs have not been helpful; they were trying to promote free-market principles in a context where markets were dysfunctional or simply failing. Even though policymakers have learned from their policy mistakes and have been implementing corrective measures such as gradually reviving sites-and-services programs in many countries (Box 4.2), the laissez-faire approach adopted during the structural adjustment era has been detrimental to affordable housing development across the continent. 


\section{Box 4.2 Increasing the Supply of Low-Cost Serviced Land in Côte d'Ivoire}

Côte d'Ivoire was one of the many countries that launched sites-and-services programs in the 1970s. As in many other African countries, the program was abandoned following the implementation of the SAPs.

In 2014, however, the Ivorian government launched a new sites-andservice scheme called Lotissement à Equipement Modéré, popularly known by its acronym LEM. LEM is one component of the presidential housing program for low-income households. It is in a pilot phase; four planned sites totaling 58 hectares are reserved around the city of Abidjan for this program.

LEM targets social groups with irregular income streams, particularly households living in slums and first-time homebuyers. The program was created to help slum dwellers to build better self-help housing, in a planned environment. LEM makes use of existing land reserves through a form of developer contribution-donation (natural contribution) from private developers worth $2.5-5$ percent of the serviced land that the state has approved for private formal development. Stakeholders have lauded LEM as the most affordable and realistic means to rehouse low-income households in better conditions.

LEM beneficiaries in the district of Abidjan receive serviced and titled plots of either 80 square meters $\left(\mathrm{m}^{2}\right)$ or $108 \mathrm{~m}^{2}$, while recipients outside Abidjan get plots with a minimum size of $120 \mathrm{~m}^{2}$. The $80 \mathrm{~m}^{2}$ plots can accommodate a three-room house, while the $108 \mathrm{~m}^{2}$ plots can accommodate three to four rooms. All LEM plots will come equipped with services such as water, electricity, sewerage, and access to paved primary and secondary road infrastructure. The government has identified future land reserves of 850 hectares across the country for LEM. To improve affordability, land for LEM is based on an emphyteutic lease, a flexible system. After 20 years, the lease can be transferred into purchase when the lease has been paid off.

LEM plots will be located in zoned and well-planned areas, and will make provision for commercial real estate and more expensive housing, thus ensuring a mixed-use community. Moreover, a large proportion of each planning zone will be dedicated to community spaces, access roads, green spaces, and social facilities, such as schools, clinics, and commercial centers. The zones will also be equipped with collective parking lots and garbage disposal sites. Land titles will be provided to beneficiaries who meet all requirements.

Source: Based on information obtained during fact-finding mission in Côte d'Ivoire, November 2014. 


\subsection{Implications of Unclear Land Tenure Regimes and Rights}

Notwithstanding that African governments have been adopting some policies to increase the supply of land for affordable housing, very few have succeeded in opening up access to land for a vast swath of their populations. Governments are finding it increasingly difficult to locate large land parcels in urban areas for mass housing projects. Even in countries where land belongs to the state and citizens have land use rights, accessing vast swaths of land for housing remains a major challenge. For example, to meet the demand for affordable housing in Addis Ababa in Ethiopia, where the state owns all land and no customary land regime is in play, the government needs to build 50,000 units per year, for which it needs 650 hectares of land. However, finding such vast land in the city limit of 54,000 hectares has been a challenge. As a result, most new housing developments are located far from the city center and have limited basic infrastructure services such as water, electricity, roads, and sewerage systems. This challenge is even more prominent in countries operating under a pluralistic land tenure system.

The effects of these multiple tenure regimes on formal housing markets are manifold. Not only do they diminish the security of land rights of housing consumers, they also create an artificial land shortage, which further inhibits the delivery of land for housing developments. Moreover, unclear land tenure regimes, which often are fraught with loopholes and inconsistencies, dissuade private investment in the housing market. The result has been greater land speculation and rising housing prices. In order to address the continent's growing housing crisis, African governments need to take a stand on the debate over the formalization of land rights in order to increase the efficiency of land delivery systems.

\subsubsection{The Land Formalization Debate}

The establishment of a regime of individual property rights in land and housing is considered the cornerstone of an enabling housing policy regime (Angel 2000). In Africa, however, there is an ongoing debate on 
the relative merits and wisdom of recognizing statutory individual property rights as a universal solution to tenure security, particularly for the poor. The policy debate on land formalization was given a new impulse by the arguments of the Peruvian economist Hernando De Soto in 2000.

De Soto (2000) argues that the registration of informal land assets and their transformation into formal individual property rights would be the main way for rural and urban poor households in developing countries to join the formal market. By so doing, he argues, households would achieve the benefits of development, investment, and economic growth. Indeed, some research in the African context supports these claims. One school of thought argues that a clear demand for accessible and affordable processes of land formalization is emerging anyway. For example, Benjaminsen et al. (2008) point out that in the peri-urban areas of the cotton zone in Mali, private and alienable land holdings are fast replacing the customary tenure system. This growing demand for titled land is significantly driven by rapid population growth and the commercialization of agriculture.

However, critiques of land formalization programs highlight the weak capacities of governments and the fallacy of assumptions such as those from de Soto mentioned above. It is reported that although the incidence of titling is higher in East and Southern Africa, titling does not necessarily provide sufficient tenure security in these regions (Toulmin 2008). In addition, the critiques point to the dangers of such programs in aggravating socioeconomic inequalities. The larger critique of land formalization programs in Africa is that they represent the "imposition of alien [i.e., Western] legal and cultural practices" in an institutional setting that "differs so profoundly from the legal and cultural setting from which they are taken" (Bromley 2008: 21-23). Furthermore, the "object of transplantation" (i.e., land titles) does not function like it is supposed to in the Western environment, as it lacks the same cultural, legal, and economic institutions (Bromley 2008: 21-23). As Deininger and Feder (2009) argue, it is important to note that the "formalization of land rights should not be viewed as a panacea and that interventions should be decided only after a careful diagnosis of the policy, social, and governance environment."

Although it is important to acknowledge the limitations of land formalization programs, it is also clear that much of the urban expansion 


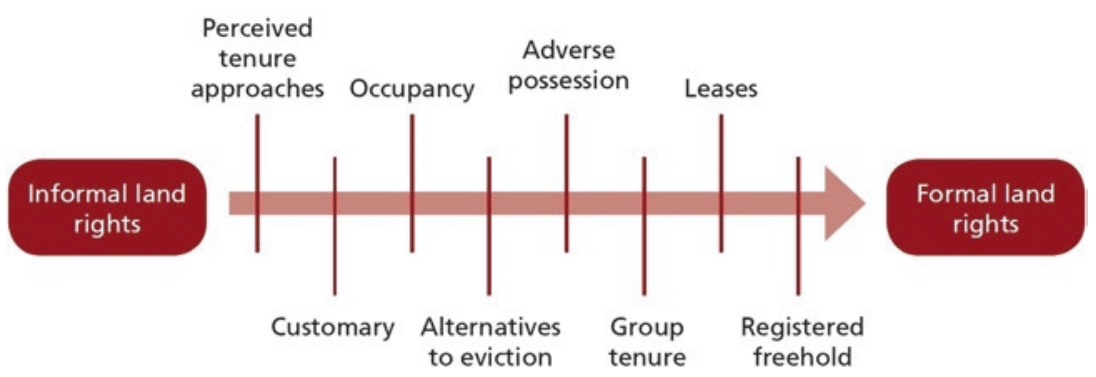

Fig. 4.2 Continuum of land rights (Source: UN-Habitat (2012b))

now taking place in Africa is following market principles that are primarily driven by households and businesses. For this reason-whether formally or informally-land market pressure will continue to be exerted onto urban, peri-urban, and even rural areas.

There is a growing consensus in land policy circles that, in the long run, individual property rights are needed to provide the degree of land tenure security that will be the basis for a functioning formal land market, mortgage financing, and private investment in housing (World Bank 2003). The Global Land Tool Network (GLTN) advocates that land rights should be seen as a continuum-from perceived and de facto tenure at the informal end of the continuum to registered freehold at the more formal end (Fig. 4.2). This continuum underscores that land tenure involves a complex set of informal and formal rights that range from various rights of occupancy and use to full rights of ownership and disposal of the land.

Better efforts to formalize land rights are required to guide this new development. Formal and informal rules governing property acquisition, sale, development, and use will be critical in creating predictable, vibrant, and efficient housing markets in Africa. In the long run, individual property rights are needed to provide the degree of land tenure security that will be the basis of a functioning formal land market, mortgage financing, and private investment in housing. The question for the housing sector is thus not whether formalization of land rights needs to occur, but how best it can be done to avoid some of the known pitfalls of land registration. Deininger et al. (2009) "suggest not only that implementing a 
decentralized, transparent, and cost-effective process of land registration is possible but also that failure to do so may squander significant economic and possibly social benefits." Nonetheless, it is worth noting that, not all social groups need or benefit from formal land rights, at least in the short to medium terms.

\subsubsection{Land Delivery Systems}

Land for housing in most African countries is provided through three main delivery systems.

Formal Private Delivery System The formal private land delivery system most closely resembles the system of private property prevalent in developed countries. In this system, land parcels are developed and sold by private actors such as property development companies. These transactions usually come with full legal rights, a property title, or equivalent documentation. Second are public, formal, or government-controlled land delivery systems, which allocate residential plots to various social groups at below-market prices. Through this delivery channel, the state can also provide large parcels of land to developers and cooperatives for affordable housing construction. The third and predominant land delivery system is the customary and informal system, in which unserviced land is sold or transferred with no legal guarantees or property title.

As discussed above, most African countries today are characterized by an uneasy coexistence of customary and statutory land delivery systems, giving rise to a variety of tenure situations. Moreover, as African cities rapidly expand into the urban-rural periphery, there is frequently a direct clash between state power and legal claims to land management and those of customary authorities. As a result, the general spatial pattern of land tenure modes is that the more secure, formal tenure modes are usually to be found nearer to city centers (Mattaei and Mandimika 2014).

Durand-Lasserve et al. (2013), for instance, found that plots obtained under private and public land access modes in Bamako generally occupied relatively central locations of the city. The authors also found that plots with secure forms of tenure are on average more expensive than plots with less-secure forms of tenure. In Bamako, plots with property 
titles were estimated to be worth 1.4-5.7 times the price of similar plots with no legal rights. This demonstrates the high value of tenure security and legal transferability. These findings may probably be applied to most African cities. They indicate the steady growth of land markets, even in locations that were previously not urban. However, African governments will need to create flexible tenure systems that are simple and provide secure tenure in order to accelerate land delivery.

The Customary Delivery System Customary authorities, including traditional chiefs, continue to play an important role in land management and land allocation in many African countries. Particularly in rural areas, these authorities often have more power to allocate land than formal land administration systems do. Their legitimacy is based on their claim to represent local populations and customs. In Ghana, for instance, the system of customary land rights enshrined in the 1992 constitution is seen as progressive and egalitarian, with checks and balances (UN-Habitat 2011).

However, elsewhere on the continent customary land allocation is not held in as high regard as in Ghana. In neighboring Côte d'Ivoire, for example, officials and notaries claim that many chiefs have long gone beyond their traditional roles and have become land brokers, merely out to make a profit rather than primarily serving as custodians of ancestral land. Rather than enshrine customary land allocation in the constitution, as Ghana has done, the government of Côte d'Ivoire has adopted compensation framework for the acquisition of customary land (Box 4.3).

\section{Box 4.3 Purging Customary Land as a Land Delivery Mechanism in Côte d'Ivoire}

Since 2013, the buying of customary land has been the law in Côte d'Ivoire. The policy was instituted to help the state achieve three main objectives: (1) reduce the cost of land and housing, (2) reduce the risk of litigation from customary owners, and (3) reduce the incidence of land speculation. According to decree $n^{\circ}$ 2013-224 of March 22, 2013, all purchases of customary land must be done at scheduled rates: a maximum of 2000 FCFA ( US\$3.22) per square meter in the main city of Abidjan; a maximum of 1500 FCFA ( US\$2.42) per square meter in Yamoussoukro, the capital; and a maximum of 600 FCFA ( US\$1) per square meter in all other districts and cities around the country. 
New land acquisition negotiations for projects considered to be in the public interest take place between the government and multiple landowners with chiefs in the background. Government officials draw up a land map to be able to demarcate and register the land (cadaster) with the property owners to assess how much the state has to pay and to whom. Then it implements the decree and establishes a protocol of payment. In the case of housing projects, the state then buys the parcels and distributes them to developers. Beforehand, to preempt litigation, the state prepares a general urban plan (like a master plan). The process is successful as a way of removing the risks of dealing with customary land. It is only property owners themselves who often do not know how to deal with the cash payments. To reduce the risk of conflict among property owners, the state allows them to opt for a new house in the development instead of an instant cash payment.

Source: Based on information obtained during fact-finding mission in Côte d'Ivoire, November 2014.

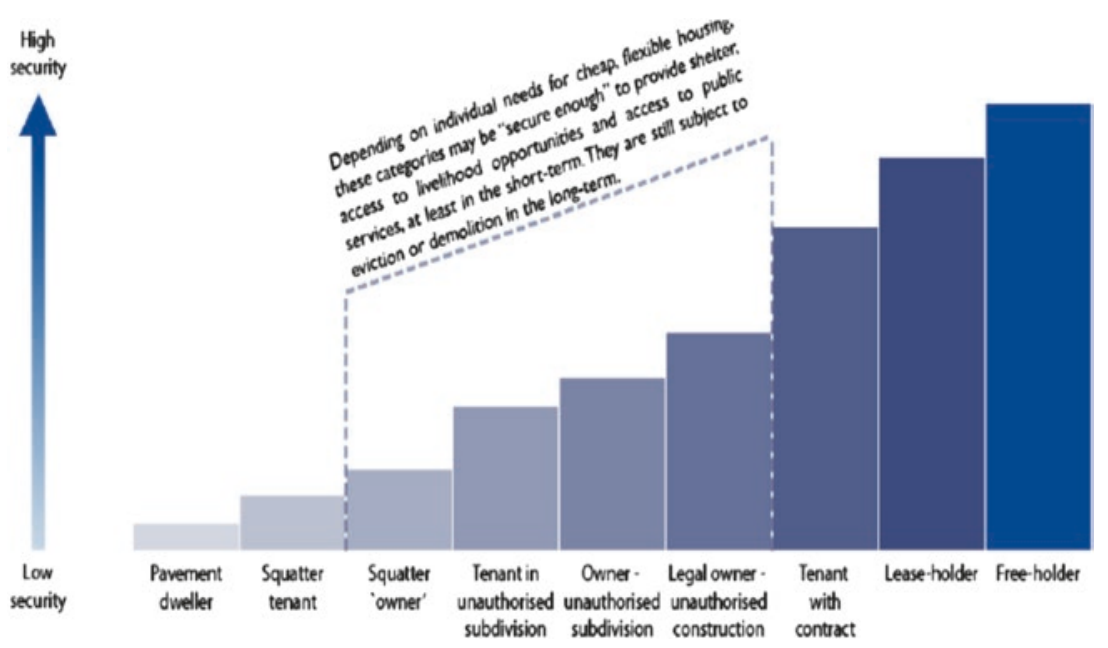

Fig. 4.3 The urban tenure continuum (Source: Payne et al. (2014))

The Informal Delivery System A fundamental problem for poor urban households across the continent is their inability to access secure, welllocated, and affordable land for even the most basic housing needs. Figure 4.3 illustrates the continuum of tenure arrangements that typically 
exist in urban centers in many developing countries, including African cities. The least secure tenure arrangements are those on the left, with tenure security increasing progressively as one moves to the right. However, the progressively higher steps between tenure statuses also represent the increasing difficulty of moving into a more secure tenure status.

As highlighted in Fig. 4.3, urban land markets operate on multiple levels, ranging from the most informal to the highly formalized. If the market is understood as a series of transactions and exchanges, supported by sets of rules and institutions, it is clear that the market is at work even in the alternative, informal mechanisms through which most people meet their needs for land and housing. Indeed, the market influences the value of land and housing built on it and, hence, affects affordability (Napier 2013). In other words, land markets do exist in Africa, although a majority of these transactions occur informally. The inefficiencies related to that informality and related issues discussed above have deleterious effects on affordability.

\section{The Pragmatic and Flexible Delivery System A number of practical inter-} ventions can be implemented to incrementally improve tenure security in the continent's land market, as well as in programs to upgrade slums or informal settlements. However, there are a number of contextual factors that will have a bearing on the potential for incremental tenure security. They include good governance and democratization through a more advanced decentralization process, policy and legal frameworks; the state's capacity and willingness to innovate, especially at municipal levels; and the strength of civil society organizations that actively support vulnerable communities.

It is more efficient to build on what already exists-both in law and in local practice-in order to achieve more immediate upgrading and tenure security results. The experiences of the cities of Johannesburg and Huambo, respectively, in South Africa and Angola show that one way to do this effectively is to identify the laws that can be adapted innovatively (see Royston 2013 for more on the legal discussions). In Johannesburg, for instance, the city municipality legally recognized several informal settlements, which paved the way for the provision of basic infrastructure services, tenure security, as well as land use planning and integration into 
the municipal administrative system. Another is to consider confirming the status of local practices and adding municipal or administrative weight to them, as in Huambo, Angola. In Huambo, the council adopted temporary and flexible resolutions that enabled households to obtain upgradeable land occupation licenses, known as Licença de arrematação. This administrative recognition helped in closing gaps in the Angolan land law.

A Community Land Trust (CLT) is another model that can be used to provide access to land and housing to people who are otherwise denied access. A CLT can be a useful tool in keeping housing affordable, as it prohibits speculation and manages land for the common good of the community. The CLT model has been experimented to provide tenure security in an informal settlement upgrading project in Voi, Kenya (Bassett 2005). In Nigeria, Gusah (2012) has proposed the adoption of a CLT model based on the shared equity housing approach that evolved in the United States in the late 1960s. A CLT is seen as a possible compromise between the country's primary land policy instrument, the Land Use Act of 1978, which vests ownership of all land in Nigeria's federal and state governments, and the traditional, historic claims of local communities, such as those in Nigeria's capital, Abuja, which provide the city with its most affordable housing. The title documentation under the CLT would not be issued in the names of individuals, but rather in the name of the community as a whole, as a trust on behalf of all the land-owning individuals - in keeping with the traditional concept of the communal ownership of land (Gusah 2012).

Similarly, the Namibian government has developed the Flexible Land Tenure System (FLTS) as an innovative way to provide affordable tenure security for residents living in informal urban settlements. The FLTS concept derives from the government's need to create upgradeable alternative land tenure options for informal settlements to complement the current formal system of freehold tenure, which is cumbersome, costly, and out of reach of the urban poor. The FLTS is a community-driven process that offers the possibility of registration of individual rights under group ownership, an approach that is currently unique to this process. 


\subsection{Low-Density Urban Expansion and a Massive Infrastructure Deficit}

Over the last two decades, the concept of urban sprawl has gained considerable attention in Africa, partly owing to the continent's rapid pace of urbanization. Today, much of Africa's urban expansion is occurring through unplanned and low-density consumption of rural land. On the one hand, this urban sprawl is being driven by cultural preferences. Some housing experts argue that African households, even in urban areas, prefer to own a detached house, surrounded by a plot of land. This longstanding cultural preference fuels the growth of both formal and informal housing areas. On the other hand, poor urban planning, which is a function of a lack of political will and vision, as well as limited government capacities, appears to be the key factor contributing to urban sprawl in many countries. Land prices also play an important role in sprawling, low-density developments: it is significantly less expensive to buy a strip of land in peri-urban or rural areas than in the city center in many countries. As explained above, this is related to the fact that higher land tenure security is associated with city centers.

As African cities rapidly expand into rural areas, this presents both opportunities and challenges. Africa's low-density urban sprawl entails long-term financial, social, and environmental costs for rural livelihoods and future urban settlements. On the one hand, significant swaths of new land may become available for housing and other urban uses. Exploiting the full potential of this new land for housing depends on the availability of transport, infrastructure, and service connections being built by the state and private-sector actors. There exists a real opportunity for African governments to move away from congested large cities to build new satellite cities that are well connected with all required services to host the growing population. However, the limited capacity of both national and local governments presents a major obstacle to providing basic bulk services and infrastructure. On the other hand, rural livelihoods and agriculture will also come under threat as African cities rapidly grow and put pressure on agricultural land. As approximately 60 percent of the continent's population still derives its livelihood and income primarily from 
Table 4.3 Africa's infrastructure deficit

\begin{tabular}{|c|c|c|c|c|}
\hline \multicolumn{5}{|c|}{$\%$ of population with access } \\
\hline Infrastructure & Africa & $\begin{array}{l}\text { South } \\
\text { Asia }\end{array}$ & $\begin{array}{l}\text { Latin America and } \\
\text { Caribbean }\end{array}$ & $\begin{array}{l}\text { OECD } \\
\text { Countries }\end{array}$ \\
\hline Electricity & $43^{a}$ & 78 & 96 & 100 \\
\hline Improved water source & 66 & 92 & 95 & 93 \\
\hline $\begin{array}{l}\text { Improved sanitation } \\
\text { facilities }\end{array}$ & 40 & 45 & 83 & 98 \\
\hline
\end{tabular}

Source: World Bank (data for latest year available)

aData from IEA, World Energy Outlook 2013

farming, livestock production, and related activities, it is imperative to identify and promote promising rural-urban linkages as well as positive externalities through an efficient allocation and use of the land to avoid jeopardizing the livelihood of rural dwellers.

Furthermore, the expansion of cities across Africa is accentuating the clash between customary and statutory land tenure systems and cultures as noted in the preceding section. In most countries today, towns and cities are gradually swallowing up villages whose land development modes are still largely dominated by customary systems. As observed by some land experts, these village inhabitants presently do not see the need to apply for a formal land title since they believe the land belongs to them. The absorption into newly urbanizing areas of previously rural land thus engenders a clash in terms of perceptions of property rights that will cause future conflicts and complicate efforts to clarify land rights.

The urban sprawling problem goes hand in hand with the lack of adequate infrastructure. African countries lag behind other developing countries in terms of infrastructure provision (Table 4.3). For instance, this infrastructure deficit is largest in access to electricity as well as water and sanitation services.

For instance, only 43 percent of African households have access to electricity compared with 41 percent of households in low-income countries outside Africa. Even though the continent's stock of paved roads and the population's access to pipe-borne water and sanitation have increased over the years, the continent still lags behind other developing economies when it comes to the provision of infrastructure and basic services. Moreover, in many countries, the overstretched infrastructural network 
compounds the problem. For instance, Luanda in Angola, which was built for approximately 1 million residents, currently houses over 6.5 million. The influx of new populations coupled with the natural growth in urban expansion is putting increasing pressure on the poorly maintained infrastructure networks, not only in Luanda but also in many African cities including Lagos, Nairobi, Dakar, Cairo, and so on.

This extensive infrastructure deficit has severe implications for the continent's housing sector, given that decent and adequate housing requires basic infrastructure services such as roads, good transportation access, electricity, water, and sewerage. In South Africa, for instance, the provision of infrastructure and bulk services accounts for 23 percent of the total cost for an affordable house. Likewise, in Kenya, the lack of infrastructure and serviced plots emerges as a major constraint to affordable housing, accounting for over 20 percent of the cost of new housing. The high cost of land in Kenya is a major impediment to the provision of roads and other bulk infrastructure, according to government officials. In neighboring Ethiopia, the provision of trunk infrastructure accounts for 15 percent of the total cost of housing under the government's social housing program.

Infrastructure, in particular access to efficient transport infrastructure, shapes cities. As a result, affordable housing cannot be looked at in isolation from reliable transport links and transport costs. In most countries, available land parcels and new housing developments are far from the city center and are often not connected to it by public transit. Besides putting considerable strain on household budgets, poor transport networks reinforce physical barriers, resulting in urban residential segregation. The housing developments in Kilamba and Zango offer a glimpse of the divided housing market in Angola. Residents in these cities must commute for $25-40 \mathrm{~km}$ a day to and from their places of employment in the city center in Luanda. With commuting times of up to two hours, many households wake up as early as 5:00 AM to go to work and return only at about 9:00 PM when traffic has lessened. In our discussions with housing stakeholders in South Africa, it was noted that many households living in the periphery of Johannesburg spend about 40 percent of their monthly income on the costs of commuting to and from work. As a result, these households are left with very little income to spend on goods and services 
such as housing, health care, and education, among others. A lesson that could be learned from this situation is that effective urban planning and management systems should always make provision for integrated transport networks, particularly so for peri-urban housing development projects.

High costs and extensive delays in providing bulk infrastructure intrinsically affect housing affordability in Africa. Governments, in partnership with the private sector, need to find cost-effective solutions to meeting the capital costs of providing basic bulk infrastructure. In most countries, the responsibility for the provision of basic physical infrastructure, land use planning, and development rests with the government. However, limited resources, weak institutional capacities, and lack of coordination between multiple government agencies entrusted with the tasks of service delivery further complicate the infrastructure challenge.

Furthermore, the level of investment required for infrastructure provision in peri-urban settlements (whether formal or informal) can be prohibitive, owing to the cost of retrofitting bulk infrastructure, especially in unplanned areas. Without careful urban planning and the timely delivery of basic infrastructure to support new housing developmentsparticularly in urban peripheries - the costs of providing physical infrastructure are likely to increase significantly. This is simply due to the economics of densification: it is cheaper to provide physical infrastructure and basic services in denser areas than in low-density settlements because the fixed costs can be spread over many households.

The infrastructure challenge highlights the important link between planning, land, and finance. Collier and Venables (2014) suggest that inadequate urban planning and the failure of many African governments to build local tax systems have widened the infrastructure gap in cities. In addressing this challenge, the starting point is to plan properly and be able to map out the available land.

\subsubsection{Financing Land and Infrastructure}

Africa suffers from an acute shortage of infrastructure. The continent's ageing infrastructure continues to prevent it from realizing its full eco- 
nomic potential. Overall, Africa needs an estimated US\$93 billion per year to fill its infrastructure deficit. Mckinsey (2016) suggests that Africa will need to double its annual investment in infrastructure to US $\$ 150$ billion, which is equivalent to about 4.5 percent of Africa's GDP, in order to accelerate infrastructure development and contribute to the realization of the potential of Africa's economy. Urban and housing infrastructure could account for about US $\$ 23.25$ billion to US\$31 billion of this financing deficit. In South Africa, for instance, frequent power outages weigh heavily on the manufacturing sector's growth. In Angola, the city of Luanda, the infrastructure stock is under heavy pressure to serve a population that is 6.5 times bigger than what it was built for. These situations are rather common across African cities and highlight the fact that Africa's population growth and urbanization are placing enormous pressure on the stock of limited infrastructure. Inadequate financing has been considered as one of the major obstacles constraining Africa's infrastructure development. Lessons learned in terms of infrastructure development and recent development regarding the financing of development suggest that African governments will need to attract more private capital and mobilize resources domestically to finance its infrastructure needs including, particularly, urban and housing development.

Pinpointing how the government should pay for infrastructure services, including resource mobilization through municipalities and local governments, should be a fundamental aspect of any urban planning discussion. Some revenue tools that could be used to pay for infrastructure services include developer levies, land value capture allowing for user fees, taxes and public-private partnership (PPPs).

\subsubsection{Moving from the Dominance of Public Finance to Mobilization of Private Capital}

Financing flows into Africa's infrastructure have been dominated by public budgets and equity finance, as well as investment from traditional and new development partners such as China, whose investment has grown appreciably over the years, from US\$313 million in 2000 to US $\$ 4.4$ billion in 2012 (Gutman et al. 2015). Funding from multilat- 
eral development banks such as the African Development Bank (AfDB) and World Bank has also supported infrastructure financing and technical assistance on the continent. These institutions continuously refine their instruments and create new facilities to help fill the financing gap. The AfDB's US $\$ 3$ billion Africa50 fund and the World Bank's Global Infrastructure Facility are some investment vehicles established to close the infrastructure gap. The Africa50 Fund aims at pooling resources devoted specifically to the financing of Africa's infrastructure development.

In recent years, African governments have relied on international capital markets to raise funds for infrastructure projects, through the issuance of bonds. The overreliance on Eurobonds, especially in West Africa, as a means of raising capital to finance infrastructure projects poses risks as local currencies depreciate against the dollar, with commodity producers— such as Ghana and Nigeria — being the most exposed. Mozambique and Zambia have been similarly exposed. As the dollar strengthens, this places pressure on Eurobond yields and increases the cost of borrowing in capital markets. Moreover, compared with the energy and telecommunications sector-which have raised 78 percent of the financing mobilized through PPPs on the continent (Paulais 2012)—such mechanisms have not been widely used for urban and housing infrastructure development purposes in Africa. The difficulties of crowding in the private sector in the financing of Africa's residential real estate market and urban infrastructure are due to (1) the paucity of reliable data to guide investment decisions, (2) inadequate institutional and legal frameworks, and (3) a lack of awareness among investors. One way to attract private capital is to boost the equity investment in infrastructure. Equity investments account for 80 percent of infrastructure funding in sub-Saharan Africa. This has become an asset class that is attractive to several equity investors including pension funds, sovereign wealth funds (SWFs), and bank-sponsored investment funds. Capital raised by infrastructure funds has also been increasing (Faye and Geh 2016). As of September 2016, the total amount raised by private equity infrastructure funds with a primary geographic focus of Africa since 2013 stands at over US $\$ 2.3$ billion, according to Preqin. The challenge is to attract part of those equity investments in the urban and housing development sector. In so doing, political leaders and 
decision-makers around the continent need to put urban and housing infrastructure development high on their agendas and among their top priorities along with energy and telecommunications. They should also be eager to put in place an enabling environment conducive to attracting such private capital.

\subsubsection{Tapping into the Contractual Savings Industry: Expansion of the Caisse des Dépôts Model}

Financing urban and housing infrastructure development is a big-ticket item and as such requires long-term financing. The contractual savings industry is one of the natural channels through which long-term resources could be mobilized domestically. This includes insurance companies, pension funds, and SWFs. Between 2009 and 2014, it is reported that assets under management (AUM) by African SWFs grew by about 34 percent, from US\$121 billion in 2009 to US\$162 billion in 2014. The AUM by pension funds in 10 sub-Saharan Africa countries was estimated at US\$379 billion in 2013. As per the African insurance companies, the AUM in 2012 was estimated at US\$273 billion, and projected to grow to reach US $\$ 378$ billion by 2018 , equivalent to a 37 percent increase. Despite, the sizeable amount of long-term resources it manages, the contractual savings industry has until recently been untapped, but new developments show an increased interest in leveraging savings from institutional investors.

Inspired by Morocco's state-owned Caisse de Dépôt et de Gestion (Deposit and Management Fund, or CDG), many French-speaking countries in sub-Saharan Africa have sought to replicate the success of this nonbank financial institution, which manages the savings of many institutional investors such as the National Savings Bank and the National Social Security Fund. With about US\$25 billion in assets under management, CDG is the biggest financial institution in Morocco, with a market share of about 10 percent. Such government-backed institutions typically have a dual mandate to (1) mobilize regulated funds and deposits for long-term investments and (2) invest these resources in urban development, infrastructure, and housing projects, particularly low- 
income housing. When well established, the volume and the stability of their resources channel quasi-monetary resources into illiquid long-term investments. In addition, their fiduciary functions can be extended to a wide range of activities, from the sponsoring of PPP arrangements to the management of pension funds.

The Caisses des Dépôts model exists in Gabon, Mauritania, and Sénégal, while Benin, Cameroon, Madagascar, and Togo have recently created or are in the process of creating similar institutions. The potential of the Caisse des Dépôts model is promising, provided that they succeed in mobilizing a significant part of national savings that often stay idle outside the formal banking sector. However, a few risks must be carefully managed in order for this model to be successful. The first is linked to possible governance issues that result from the politicization of these institutions by governments using it as a financial tool for noncommercially viable projects. A rigorous project evaluation system and strong corporate governance, with an independent management team operating under strict processes, must be in place to ensure that this model functions successfully. Second, the Caisse des Dépôts model should avoid adopting market-distorting actions. These institutions should be designed as complementary, and not competitors of commercial institutions. Third, the legal and regulatory framework should be conducive enough to avoid stifling the potential of these types of institutions to contribute to financing housing development.

\subsubsection{Land Value Capture}

As discussed in Chap. 2, the absence of a reliable land registry database in many African countries is due to capacity constraints faced by government entities and agencies entrusted with land registration and administration activities. Moreover, there is a lack of a comprehensive and up-to-date mapping of the available land, including information on ownership, size, and value, which takes into account its agro-ecological features, the quality of infrastructure to service the land and other characteristics. Government entities in charge of land such as cadaster 
offices are still using obsolete and manual techniques and do not have the capacity to use modern technology including computerized system using real-time data supplied by GPS, geospatial, or satellite imagery systems. This has significantly undermined the ability of countries to properly value land, effectively manage the available land, or negotiate fair land concessions. In many countries, the lack of adequate land valuation system and weak land markets prevents several African governments to effectively mobilize domestic resources through land value capture to finance urban infrastructure.

In the current challenging and difficult global economic environment that has been exacerbated by a decline in donor funding and the scarcity of long-term financing, land value capture is an innovative financing mechanism which should be harnessed to raise domestic financing for urban infrastructure (such as transport infrastructure, education and health facilities, as well as recreational infrastructures, social facilities, and parks), which contributes to the well-being of urban dwellers. As discussed in the literature (Palmer and Berrisford (2015) and others), land value capture (LVC) is a possible solution that governments (both central and local) could apply to capture a share or all of the increase in private land value that results from public infrastructure investments or from some public decision, such as approved land use changes. For instance, public investments in transportation or sewerage often positively affect adjacent land value as it becomes more productive and valuable. Moreover, such public capital investments also increase property values, with residents willing to pay a premium in order to benefit from the positive externalities-such as increased accessibility, better schools, and employment opportunities - that often come along with the provision of most public infrastructure. The LVC is a benefit sharing mechanism that could take several forms depending on the instrument used as shown in Table 4.4. In fact, sharing the benefits created by the provision of public infrastructure can often be done through property taxes, sale of government-owned land or via preemption rights, and so on. International experiences have shown that the LVC solution has worked very well in Latin America (e.g., Colombia and Brazil), China, and Mexico. 
Table 4.4 Land value capture mechanisms

\begin{tabular}{|c|c|}
\hline Instruments & Description \\
\hline $\begin{array}{l}\text { Betterment levies/ } \\
\text { taxes }\end{array}$ & $\begin{array}{l}\text { Any tax or charge on an increase in value resulting from } \\
\text { some public action, such as the issuing of development } \\
\text { rights or the provision of infrastructure. }\end{array}$ \\
\hline $\begin{array}{l}\text { Sale of development } \\
\text { rights }\end{array}$ & $\begin{array}{l}\text { The sale of the right to convert rural land (agricultural or } \\
\text { unzoned) to urban use; and the right to build at } \\
\text { greater densities than normally would be allowed by } \\
\text { zoning rules or height restrictions. }\end{array}$ \\
\hline Public land leasing & $\begin{array}{l}\text { If the relevant local authority owns the land, it would } \\
\text { lease the land out for a period of time, thus generating } \\
\text { revenue. }\end{array}$ \\
\hline $\begin{array}{l}\text { Land acquisition } \\
\text { and resale }\end{array}$ & $\begin{array}{l}\text { The purchase of land around a development, and } \\
\text { subsequent resale of that land by the public sector or } \\
\text { relevant authority is a method to capture the full value } \\
\text { of the gains that an infrastructure investment may } \\
\text { create. }\end{array}$ \\
\hline Land sales & $\begin{array}{l}\text { This instrument relates to the sale of publicly-preferably } \\
\text { city-owned land. }\end{array}$ \\
\hline Developer exactions & $\begin{array}{l}\text { Exactions are requirements a local government places on } \\
\text { a developer to dedicate land, construct, or pay for all or } \\
\text { a portion of the costs of capital improvements needed } \\
\text { for public facilities as a condition of development } \\
\text { approval. }\end{array}$ \\
\hline Impact fees & $\begin{array}{l}\text { Impact fees are designed to cover the costs of the bulk } \\
\text { and connector infrastructure required for a new } \\
\text { property development or property development } \\
\text { improvements. }\end{array}$ \\
\hline $\begin{array}{l}\text { Negotiations and } \\
\text { voluntary } \\
\text { contributions }\end{array}$ & $\begin{array}{l}\text { A bilateral negotiation, before the investment occurs, is } \\
\text { used to determine a rate that property owners in the } \\
\text { area of influence should pay for the improvement. }\end{array}$ \\
\hline
\end{tabular}

Source: DfID and African Centre for Cities (University of Cape Town (2015))

According to Palmer and Berrisford (2015), as far as sub-Saharan Africa is concerned, all the instruments in Table 4.4 except betterment taxes could be applied. Findings in the literature regarding the applicability of the betterment taxes method in Africa have not been unequivocally conclusive. However, the DfID-ACC report highlights the fact that public land sales, land leasing, and direct contributions from owners or developers (exactions and impact fees) are the main land-based value capture methods which are likely to be implementable in Africa. 
The reality is that the use of LVCs to finance infrastructure in Africa is fairly limited. However, African cities and municipalities are gradually adopting property taxes to guide and finance the development of urban infrastructure. This approach has been commonly used in rapidly growing cities in other parts of the world, particularly in developed economies. An important feature of such taxes is that they must be closely linked to the provision of basic services. As citizens see an improvement in service delivery, their willingness to pay taxes will generally increase. However, building local tax systems is a necessary step toward developing sustainable infrastructure financing for cities. The approach used by Lagos illustrates how municipalities can build their tax systems to finance basic infrastructure and satisfy the huge demand for public services. Since 2001, successive Lagos state governments have streamlined the property tax rates, developed an electronic property database, which has digitized and enlarged the property tax registry. The Lagos state government has also increased its public outreach and community engagement practices, educating its residents about the benefits of compliance. The results have been an increase in tax receipts, while at the same time engaging residents to ensure that their tax contributions are well spent. In Ethiopia, the government has begun implementing policies that would enable it to introduce the LVC tool to raise financing for municipal infrastructure. With funding from the Bill and Melinda Gates Foundation, the government has introduced a modernized property tax system in Ethiopian cities. The new property tax system was piloted in the cities of Mek'ele, Bahir Dar.

Developer contributions and development levies are also two possible options that some municipalities on the continent have been using to finance infrastructure. Although this source of funding can be adequate for financing infrastructure within the boundaries of a development area, it is not a sufficient or sustainable source of funding for new infrastructure needs. In order to increase housing affordability for low- and middleincome families, developer levies should closely reflect the capital cost of putting the infrastructure in place. However, in situations where the government can fund infrastructure construction through tax receipts, development levies should not be used. 


\subsubsection{Financing Urban and Housing Infrastructure: Specialization Matters}

Urban and housing infrastructure development is a complex and very demanding field and requires dedicated teams of professionals, technical resources, and instruments relevant to the sector. Some countries are cognizant of those requirements. Burkina Faso, Cameroon, Ghana, Kenya, Mali, Nigeria, Sénégal, and South Africa, for instance, have created dedicated facilities to support public investments in the housing market. However, most of these facilities depend heavily on government budgets. Apart from the Development Bank of South Africa (DBSA), most of these institutions do not have a sustainable mechanism for mobilizing domestic resources as they rely heavily on government budgetary allocations and merely serve as conduits for donor support. The DBSA, by contrast, has diversified funding sources including bonds, money market paper, and committed foreign lines of credit with commercial banks. As of November 2013, the DBSA had raised R 20.25 billion (US\$1.7 billion) in the domestic bond market, with the proceeds used to finance infrastructure development even at municipality level. However, only a small portion of this funding has been allocated to housing. Another notable example of a specialized institution supporting domestic infrastructure financing is The Infrastructure Bank (TIB) of Nigeria. TIB, which is majority owned by the private sector, is mandated to finance large-scale, long-term infrastructure projects in Nigeria such as mass housing, water provision, and transport, among other municipal services. More efforts are needed to put in place specialized institutions able to successfully deliver the requirements needed. There is therefore a need to think about appropriate institutions or facilities dedicated to urban and housing infrastructure development with adequate governance structure, mechanisms, and procedures that could enable them to raise adequate financing for housing development.

New and more adequate instruments are needed to mobilize market resources for urban infrastructure and housing developments in Africa. In mature markets, structured finance instruments are used to ring-fence cash flows generated by newly developed infrastructure, which are then 
allocated to capital market investors. Revenue bonds provide a good example of such a structure. These are municipal bonds that finance income-generating projects and are secured by a specified revenue source, such as lease payments, tolls, or tax income. Typically, a special purpose vehicle (SPV) or an ad hoc project company is created to ring-fence the revenue streams and ensure their transfer to bondholders. Generally, the creditworthiness of the sponsoring entity needs to be enhanced by an external guarantor, or, as it is often done in the United States, through a reserve fund capitalized by public resources. The economics of revenue bonds is simpler than securitization, and can be used in place of sukuks where Islamic finance is needed. Several Nigerian states have already issued revenue bonds, and the DBSA plans to launch this instrument in the near future.

Revenue bonds can help municipalities reduce their dependence on conditional cash transfers, such as in Uganda and Ethiopia, or on ad hoc revenue, such as land transfer taxes in Kenya, to fund infrastructure and service delivery. Some countries have also created specialized financing tools to support municipalities such as the Municipal Infrastructure Fund (Fonds d'Équipement Communal, or FEC) in Morocco, the Fund for Mutual Assistance (Fonds Spécial d'Equipement et d'Intervention Intercommunale, FEICOM) in Cameroon, or the Municipal Development Agency (Agence de Développement Municipal, ADM) in Sénégal. In Cameroon, for instance, FEICOM funds infrastructure projects and housing developments of local governments. In March 2014, FEICOM signed a partnership agreement with Crédit Foncier du Cameroon (CFC), Cameroon's leading mortgage lender, wherein the latter committed to provide a CFAF 10 billion (US\$19.9 million) line of credit to finance low-income housing projects through local municipalities. If properly managed and structured, such an initiative has the potential to empower local governments, which are closer to the population, to address the housing and infrastructure needs in their municipalities.

Hybrid instruments can also be envisaged for the provision of urban infrastructure, depending on the degree of capital market development as well as institutional investors' expertise. New financing modalities can widen the funding bases, particularly of investors with a high risk-return appetite. Developing new financing mechanisms to support urban infra- 
structure development is crucial for building sustainable cities as the continent rapidly urbanizes. The availability of reliable data to guide investors' decision will be vital in mobilizing the required private capital for infrastructure and housing developments. In recent years, two regional initiatives have made significant strides in this respect, the Africa Infrastructure Diagnostic, although this has been a one-time initiative, and the Sokoni internet platform. However, more still needs to be done in unifying data collection efforts for infrastructure projects and housing finance among stakeholders, including DFIs, development partners, governments, and the private sector.

\subsection{Increasing Land Supply and Infrastructure}

The preceding discussions have clearly identified the key challenges related to the provision of land and infrastructure, which hamper affordable housing development delivery. Experience indicates that increasing the supply of land and infrastructure is a crucial part of solving issues of housing availability and affordability. Measures successfully implemented in some countries have included reforms to increase efficiency in land markets and expand access to land for residential development. The provision of basic infrastructure and services is another critical component of housing supply that is often overlooked but has a huge impact on affordability. Strengthening certainty, reducing costs, and ensuring timeliness are key ingredients in expanding the provision of services and infrastructure for affordable housing. To this end, it is necessary to put emphasis on three key areas, which are crucial prerequisites for the provision of land and infrastructure for affordable housing: build efficient and equitable land administrations, adopt flexible mechanisms to increase the supply of land for housing, and integrated urban infrastructure and services planning into related urban development strategies. Although a range of measures have been used in countries to increase both land supply and infrastructure, the policy proposals in the following sections focus on measures that are more appropriate for the continent's land supply and planning systems. 


\subsubsection{Build Efficient and Equitable Land Administrations}

Simplifying procedures and increasing flexibility in land use is critical in expanding access to land for housing. To adequately address the continent's housing crisis, governments must make land markets work for the poor by streamlining bureaucratic procedures and reducing the associated costs for acquiring and registering land. The complex regulatory system in many countries is often based on contradictory land laws, which, as mentioned above, hinders transparency, propagates inefficiencies, and breeds corruption in land administration and management. Regulatory frameworks on land use, land development, as well as on housing and building standards have immense implications for the ability of low- and middle-income households to buy, build, or rent good-quality housing. Consolidating the myriad legislation, including administrative frameworks, laws, and regulations governing land markets, is not just a priority but also a crucial first step in building efficient land markets. Kenya's passage of a new and consolidated suite of land laws in 2012 demonstrates how this can be done.

\subsubsection{Introduce Flexible Land Tenure Regimes to Accelerate Land Delivery}

Governments should adopt flexible and innovative approaches in order to incrementally formalize land markets and secure tenure rights. At best, land formalization programs in Africa have had mixed results. This failure has as much to do with the pace as it does with the scale of reforms. Rather than implementing a one-size-fits-all land formalization program, any land titling initiative should recognize the existence of a continuum of land rights that recognizes different sources of land access and land use patterns.

The important implication of the continuum of land rights is that populations in different land tenure situations have distinct land formalization needs and priorities: there is no one-size-fits-all recipe that applies 
to all categories. This observation is illustrated in Fig. 4.4, which shows the case of three common groups of housing stakeholders.

First, buyers of homes in formally planned housing developments will require formal land rights in the form of individual, freehold titles, in large part because these are required as collateral for mortgage loans. Individual titles are thus a standard element of housing projects planned and developed by the formal private sector. However, the needs of slum dwellers will vary depending on their circumstance and legal position. Those residents of urban slums whose land occupations are legally disputed or otherwise unresolved will not be eligible for formal freehold titles. Instead, the short-term priority for this group of housing stakeholders will be to obtain a moratorium on eviction, and secure tenure through land occupancy permits, or other such legal certificate. Once legal occupancy has been secured, the medium- to long-term priority for these populations may be to obtain formal, freehold title, if needed. Even

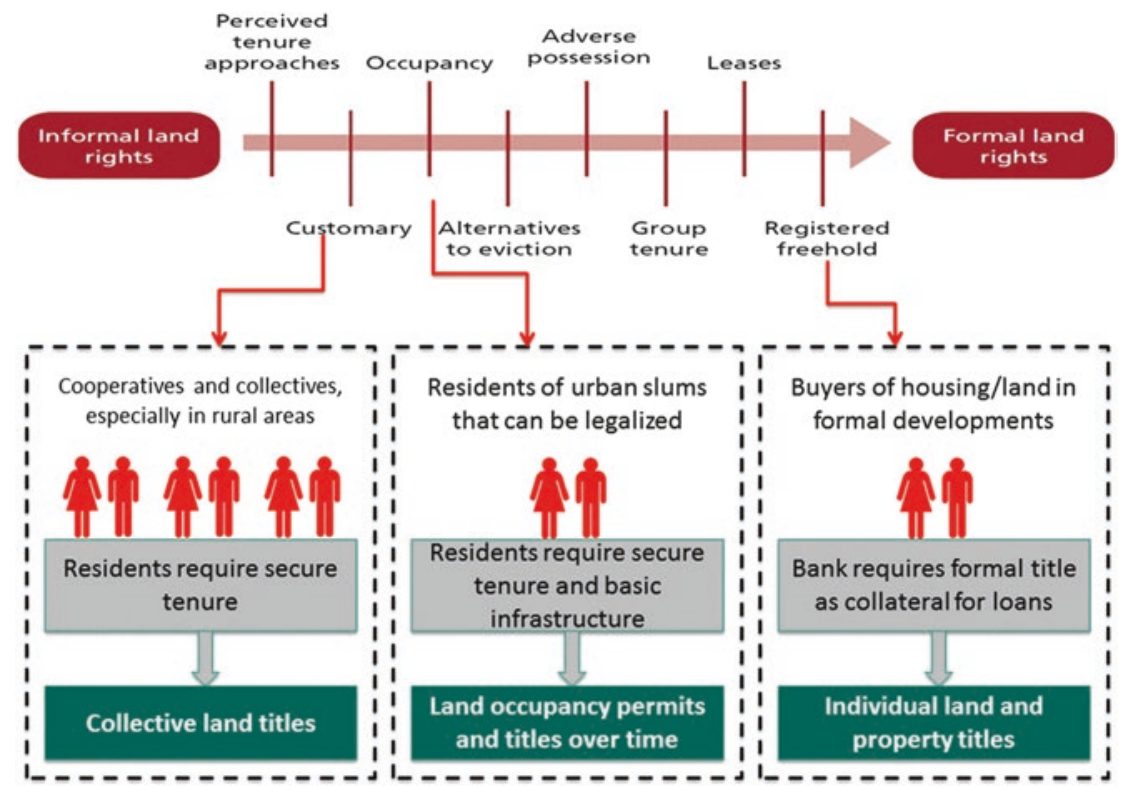

Fig. 4.4 Land titling priorities for selected housing stakeholders (Source: Adapted from UN-Habitat's continuum of land rights) 
in the latter case, however, freehold title may not necessarily be desirable for these residents, if it is accompanied by massive displacement as a result of rising land values following titling.

Last, rural and peri-urban villagers, cooperatives or collectives, may not need to title their land at all, provided that their land occupation is uncontested. In many countries, the land of these communities will have been allocated and secured through customary channels. Even if their land occupation is informal, these communities may enjoy sufficient tenure security, provided there is no active land market that will threaten to displace them. Therefore, formal and individual land titles will not be necessary. In fact, in the case of some rural communities, individual title will even be considered harmful — and culturally alien — to the collective, and may therefore be rejected as inappropriate to the needs and practices of these communities.

\subsubsection{Promote Community Participation in Land Formalization Processes}

In rural areas and informal settlements in particular, governments should be open to alternative approaches to land formalization, involving local partners and using informal approaches. In some areas, such as informal settlements, state agencies may not be the best-placed institutions to carry out enumerations of local residents and rights holders, because of their lack of knowledge of the area or because of potential hostility toward the state in these communities. In such cases, community-based approaches may be more suitable. Community-based organizations are able to implement a local enumeration process in the settlements that they cover much more effectively than the state can.

\subsubsection{Strengthen Institutional Capacity to Deliver on Land Reforms}

Governments need to strengthen the capacities of land institutions and actors in order to promote good land governance and management. In most African countries today, governments, including local administra- 
tions, are increasingly playing an important role in land management and planning. However, most of these efforts have been piecemeal. Halfhearted decentralization efforts, as in Cameroon, have failed to improve efficiency in land administration and registry records management. Complete fiscal decentralization, implying the transfer of resources from the central government and the empowerment of municipalities to mobilize financial resources must accompany the delegation of decisionmaking powers from central to local governments. Most importantly, the provision of technical skills enhancement programs through appropriate and continuous professional training as well as the adoption of modern technology, including remote sensing toll for land demarcation and mapping, will improve the management capacity of governments to increase the quality of services provided and increase efficiency in land administration.

\subsubsection{Revive Sites-and-Services Programs}

Increasing the availability of low-cost serviced land for housing is critical for increasing the supply of housing at prices affordable to low- and middle-income households. Between the 1960s and 1980s, sites-andservices programs played an important role in increasing the supply of affordable housing in many African countries. These programs involve the development of land and the provision of bulk infrastructure, which is then sold to various social groups and developers at below-market rates. They have the potential to better reach many more households at the bottom of the income ladder than conventional social housing programs. Well-planned sites-and-services projects have the potential to increase the supply of titled and serviced land strips to poor families that would otherwise be impossible for them to access due to their limited household budgets. As mentioned above, Côte d'Ivoire's rebirth of its sites-andservices program, LEM, demonstrates how these programs can be the product of collaboration with private developers, with land as a key contribution from the public sector. Another component of LEM worth noting is the mixed-use and mixed-income nature of planned LEM sites. These are positive features that can help LEM neighborhoods avoid some of the pitfalls noticed in single-use social housing areas. 


\subsubsection{Leverage Land Readjustment Programs for Urban Redevelopment}

Land readjustment is another method governments can use to assemble and increase the availability of land for housing and infrastructure. This mechanism basically involves the exchange of plots or property rights between private and public entities in a way that is mutually beneficial to the parties involved. Land readjustment has the potential to be useful in Africa as it addresses the major impediment of assembling fragmented land sites for housing redevelopment programs and projects. In cities with a high degree of private landownership, local governments might apply a land readjustment policy to access land for the development of infrastructure, particularly in the urban periphery. Typically, a municipality, local government, or a professional organization works on behalf of the state with local landowners to obtain a right of way for the proposed infrastructure networks in order to get them to agree to a land readjustment or assembly process. The landowners are compensated for the loss of part of their properties through land value gains. In return, the government builds roads, public amenities, utilities, and social spaces within the area and may reserve some land for sales to recover its infrastructure costs. Some land can also be set aside for development of affordable housing. Many forms of land readjustment or pooling are possible, depending on the capacity of the local administration and the willingness of the landowners to participate in the process.

\subsubsection{Control Illegal Land Invasions and Speculation}

Land speculation and hoarding pushes up prices and artificially restricts the supply of land for housing developments. In this instance, the state's intervention in checking such practices is warranted. Instituting an idle or vacant land tax is one method some governments around the world are using to curb hoarding and speculation. In Ethiopia, for example, where land prices have been sharply increasing, leaseholders are expected to add value to land before transferring their leasehold rights, in order to curb speculation. In instances where land has been acquired for residential 
purposes, leaseholders are also required to begin construction within five years; otherwise, they lose their tenure rights. Leaseholders that transfer freehold rights without completing construction are barred from participating in future bids. Moreover, individuals who transfer leasehold rights without completing at least half of the construction are entitled to just 5 percent of the transfer lease value, assuming they satisfy all other leasehold transfer modalities.

\subsubsection{Create Land by Upgrading Slums}

Slum upgrading is another potential source of land for housing as informal settlements often represent an important and often well-located reservoir of available land. A key challenge for using this land creation mechanism is to expand the formal rights of informal residents to occupy the new land so that these residents may upgrade their housing situations over time. Governments can play an active role in such a situation. In situations of stalemate within slums between structure owners and community residents who are tenants, as noticed in Nairobi, governments are in a unique position to break the impasse that stops upgrading from taking place. A solution could be found through some kind of arrangement giving tenure rights to long-standing, registered community members while compensating structure owners - either through additional housing units in a new housing development elsewhere, as in Morocco's thirdparty slum-upgrading program, or through other incentives. Governments should also partner with NGOs in slum-upgrading initiatives so as to leverage the collective knowledge of these stakeholders, who often have an inside knowledge of slum dynamics. Moreover, it is critical to involve local residents in major land transactions, especially during the planning phases. Continuously engaging the relevant stakeholders and residents through awareness campaigns at all stages of the slum-upgrading projects is key to ensuring successful outcomes.

Finally, if all other measures fail, governments can use their eminent domain powers to release land for development in the public interestfor building public infrastructure or low-income housing purposes. However, compensation should reflect market rates if the tool is to be 
acceptable to civil society. This land acquisition mechanism should be used only as a last resort, given its controversial nature as well as the associated costs-financial, political, and legal. In many African countries, civil society is becoming better organized and more powerful politically, as recent events in Tunisia and Burkina Faso have demonstrated. People are also becoming more aware of their rights. This will have important implications for land and housing markets in a subtle but crucial way: it will make it more difficult for the state and private parties to grab land, as resistance will grow. Moreover, citizens will increasingly demand better access to secure tenure and affordable, decent housing and services.

\subsubsection{Better Coordinate Transportation and Housing Programs}

Priority must be given to public transport infrastructure as the costs of traveling to and from work and accessing social facilities are intertwined with housing affordability. Transport is not often considered as a land instrument, but in fact, land strategies and transport should be considered together when planning housing developments. The availability and quality of transport options is an important infrastructure and service issue for housing — particularly, but not solely, for the urban poor. Decent public transport connections act to increase the area of land that is within reach of housing areas, business districts, or industries. Around the world, attempts to develop affordable housing on the urban periphery have frequently failed, due to the lack of infrastructure in newly urbanized areas. The ghost cities in Angola, Mexico, and Egypt provide illustrative examples. When housing is built in remote areas, cut off from social and economic activities, the risk is that these projects will either become ghost towns or fail to attract their target populations. Many policymakers frequently suggest that because the overall housing deficit is so large, even new housing in remote areas will attract buyers or tenants. However, this line of thinking underestimates the problem of "downward raiding" when higher-income households occupy housing meant for lower-income groups-for public policy objectives of housing affordability, especially when public subsidy is involved. It also underestimates the costs and dif- 
ficulty involved in "retrofitting" infrastructure once settlements have already developed. Hence, governments should play a lead role in improving connectivity across cities, particularly so for new housing developments in urban fringes.

\subsubsection{Integrate Infrastructure Planning in Urban Development Policies}

It is important to develop a comprehensive and integrated infrastructure plan as part of the urban planning process. The starting point in the infrastructure planning process should include a forecast of population growth so as to estimate the demand for housing, the land space required to accommodate the urban growth, and issues surrounding settlement density. This information will serve as a baseline for assessing infrastructure needs, as well as estimating future replacement needs. This will also enable local governments to strategically plan for future displacement costs when establishing user fees and tax levies for various type of infrastructure. It is crucial and cost-effective for infrastructure planning to precede settlement development in order to avoid the scenario of retrofitting infrastructure, and the associated prohibitive costs. What is more, the development of physical infrastructure is vital to reaping the full benefits of urbanization, improving the quality of life of African households, and increasing the industrial capacity of cities. Hence, African governments need to accelerate the construction of infrastructure such as water and sanitation, electricity, and roads, as well as other physical infrastructure, in order to transform cities into industrial economies and regional hubs.

\subsection{Conclusion}

In this chapter, we discussed the challenges and opportunities related to the provision of land and infrastructure for affordable housing in Africa. The chapter suggests that three principal challenges currently confront the formal housing sector in Africa: poor land governance, weak property 
rights and tenure security owing to the multiplicity of land tenure regimes, and the growing low-density urban expansion, which raise the cost of service provision.

Our analysis suggests that there is a need for African governments to play a decisive role in land markets. Examples of land governance reforms across Africa and in other regions highlight effective ways of dealing with issues of land access and management. Rwanda provides a good example of how to improve land rights and security. However, it is important to note that a copy-and-paste solution is not recommended. The uncertainties in land tenure regime and enforcement of property rights have significant implications related to the land formalization debate and land delivery. Even though it is clear that individual property rights are needed for the land tenure security required for a well-functioning formal land market, mortgage financing, and private investment in housing, it remains that land formalization should not be seen as a panacea and should be customized depending on the country context and market dynamics. The importance of community engagement and participation in land reforms cannot be overemphasized. In some areas, such as informal settlements, civil society can play a vital role in ensuring equity and efficiency in land market access and distribution. In many countries, civil society is becoming better organized and more powerful politically. As such, governments need to involve local residents in major land transactions and to sensitize residents to the law and the importance of collective interests.

Delivering large-scale housing developments and urban infrastructure is very demanding in terms of long-term finance. The discussion in this chapter has shown that the resources needed goes beyond what African governments' budgets can afford. It is therefore imperative, for those concerned with delivering large affordable housing developments, to put in place innovative financing mechanisms to help raise sufficient resources for land and infrastructure. These include financing schemes geared toward crowding in private capital through PPPs, putting in place necessary conditions to attract investments from the contractual savings industry and ensuring that the prerequisites are in place for increased domestic resource mobilization, through land value capture in particular. The success of such financing mechanisms would heavily depend on the exis- 
tence of a conducive enabling environment including enforcement of property rights, appropriate legal and regulatory frameworks, security of land tenure and ownership, well-functioning financial systems and adequate information and transparency systems. More specifically, for land value capture schemes to work, there is a need for an active central government putting in place the required policies, and a well- functioning decentralized system with capable and functional local governments, as well as a dynamic class of private developers.

Unlocking land supply and infrastructure for housing would require governments around the continent to adopt and enforce simple regulatory frameworks and land governance systems. Doing so will help clarify land rights and strengthen tenure security. In addition, making regulations and official standards flexible, such as by allowing smaller minimum plot sizes, can directly reduce housing costs. However, these efforts may not be helpful, if efficient and well-equipped land administrations are not in place and their capacity strengthened to deliver on land reforms.

It is also clear from the analysis in this chapter that unlocking land supply and housing infrastructure development requires efforts to ensure that infrastructure planning are integrated in urban development policies to avoid the onerous costs of retrofitting the required infrastructure entailed by poor urban planning. This includes making sure there is a better coordination of transportation and housing programs. Similarly, more efforts would be needed to take courageous and corrective measures geared toward making the land available to those in need, particularly low- and lower middle-income households and individuals. In so doing, several actions could be taken depending on the country context: (1) rekindle sites-and-services programs, given that well-planned sites-andservices projects have the potential to make land acquisition more inclusive; (2) take advantage of land readjustment programs to assemble fragmented land sites for housing redevelopment programs and projects; (3) establish appropriate legal and regulatory frameworks to avoid illegal land evasions and speculations; and (4) make more land available through slum upgrading, as informal settlements often represent an important and often well-located reservoir of available land. 


\section{Bibliography}

AfDB (African Development Bank). 2009. Cameroon-Diagnostic Study for Modernization of the Lands and Survey Sectors. Abidjan: Country Regional Department Center.

African Centre for Cities. 2015. Urban Infrastructure in Sub-Saharan AfricaHarnessing Land Values, Housing and Transport. Literature Review on Land Value Capture and Infrastructure Finance. Rondebosch: African Centre for Cities, University of Cape Town, v + 51 pp.

Amanor, K.S. 2012. Land Governance in Africa: How Historical Context Has Shaped Key Contemporary Issues Relating to Policy on Land, Framing the Debate Series No. 1. Rome: International Land Coalition.

Angel, S. 2000. Housing Policy Matters: A Global Analysis. New York: Oxford University Press.

AUC-ECA-AfDB Consortium. 2010. Land Policy in Africa: A Framework to Strengthen Land Rights, Enhance Productivity and Secure Livelihoods. Addis Ababa: Land Policy Initiative of the African Union Commission-United Nations Economic Commission for Africa-African Development Bank Consortium.

2012. Tracking Progress in Land Policy Formulation and Implementation in Africa. Addis Ababa: Land Policy Initiative of the African Union Commission-United Nations Economic Commission for Africa-African Development Bank Consortium.

- 2014. Guiding Principles on Large-Scale Land-Based Investments in Africa. Addis Ababa: United Nations Economic Commission for Africa. Augustinus, C., and K. Deininger. 2005. Innovations in Land Tenure, Reform, and Administration in Africa, Paper presented at the CGAIR System-wide Programme on Collective Action and Property Rights, United Nations Development Programme, and International Land Coalition workshop, "Land Rights for African Development: From Knowledge to Action," Nairobi, October 31-November 3.

Bassett, Ellen M. 2005. Tinkering with Tenure: The Community Land Trust Experiment in Voi, Kenya. Habitat International 29 (3): 375-398.

Benjaminsen, T.A., S. Holden, C. Lund, and E. Sjaastad. 2008. Formalisation of Land Rights: Some Empirical Evidence from Mali, Niger, and South Africa. Land Use Policy 26: 28-35.

Bromley, D.W. 2008. Formalising Property Relations in the Developing World: The Wrong Prescription for the Wrong Malady. Land Use Policy 26: 20-27. Byamugisha, F.F. 2013. Securing Africa's Land for Shared Prosperity: A Program to Scale Up Reforms and Investments. Washington, DC: World Bank and Agence Française de Développement. 
CAHF (Centre for Affordable Housing Finance in Africa). 2015. 2015 Yearbook-Housing Finance in Africa: A Review of Some of Africa's Housing Finance Markets. Parkview: CAHF.

CFS (Committee on World Food Security). 2012. Voluntary Guidelines on the Responsible Governance of Tenure of Land, Fisheries, and Forests in the Context of National Food Security. Rome: Food and Agriculture Organization.

Colin, J.-P., and P. Woodhouse. 2010. Introduction: Interpreting Land Markets in Africa. Africa 80 (1): 1-13.

Collier, P., and A.J. Venables. 2014. Housing and Urbanization in Africa Unleashing a Formal Market Process. Washington, DC: World Bank.

Crisp, B.F., and M.J. Kelly. 1999. The Socioeconomic Impacts of Structural Adjustment. International Studies Quarterly 43 (3): 533-552.

De Soto, H. 2000. The Mystery of Capital: Why Capitalism Triumphs in the West and Fails Everywhere Else. New York: Basic Books.

Deininger, K., and G. Feder. 2009. Land Registration, Governance, and Development: Evidence and Implications for Policy. World Bank Research Observer 24 (2): 233-266.

Deininger, K., D. Ayalew Ali, and T. Alemu. 2009. Impacts of Land Certification on Tenure Security, Investment, and Land Markets: Evidence from Ethiopia, Environment for Development Discussion Paper Series, EfD DP 09-11.

Doebele, W.A. 1983. Concepts of Urban Land Tenure. In Urban Land Policy: Issues and Opportunities, ed. H.B. Dunkerley, 63-107 (A World Bank Publication). London: Oxford University Press.

Durand-Lasserve, A. 2003. Land Tenure, Property System Reforms, and Emerging Urban Land Markets in Sub-Saharan Africa. Cambridge, MA: Lincoln Institute of Land Policy.

Durand-Lasserve, A., M. Durand-Lasserve, and H. Selod. 2013. A Systemic Analysis of Land Markets and Land Institutions in West African Cities. Washington, DC: World Bank.

ECA (Economic Commission for Africa). 2009. African Women's Report: Measuring Gender Inequalities in Africa-Experiences and Lessons from the African Gender and Development Index. Addis Ababa: Economic Commission for Africa, UN. Faye, Issa, and Zekebweliwai Geh. 2016. Meeting Africa's Long-term Housing Finance Needs: A Journey of a Thousand Miles? European Investment Bank Report.

Gusah, S. 2012. Community Land Trusts: A Model for Integrating Abuja's Urban Villages within the City Master Plan. In Changing Cities: Climate, Youth and Land Markets in Urban Areas, ed. Lauren E. Herzer, 141-159. Washington, DC: Wilson Center.

Gutman, Jeffrey, Amadou Sy, and Soumya Chattopadhyay. 2015. Financing African Infrastructure: Can the World Deliver? Brookings Institute, Washington, DC. 
http://www.brookings.edu/ /media/Research/Files/Reports/2015/03/ financing-african-infrastructure-gutman-sy-chattopadhyay/AGIFinancing AfricanInfrastructure_FinalWebv2.pdf?la=en.

Matthaei, E., and P. Mandimika. 2014. The Flexible Land Tenure System in Namibia: Integrating Urban Land Rights into the National Land Reform Programme, Paper presented at the Annual World Bank Conference on Land and Poverty 2014, "Integrating Land Governance into the Post-2015 Agenda," Washington, DC, March 24-27.

Mayo, S.K., and D.J. Gross. 1987. Sites and Services-and Subsidies: The Economics of Low-Cost Housing in Developing Countries. World Bank Economic Review 1 (2): 301-335.

MGI (McKinsey Global Institute). 2014. A Blueprint for Addressing the Global Affordable Housing Challenge. San Francisco/Seoul/Shanghai: McKinsey Global Institute.

2016. Lions on the Move II: Realizing the Potential of Africa's Economies. New York: McKinsey Global Institute.

Musyoka, R.M., and H. Musoga. 2015. Typologies of Land Tenure and Their Impact on Urban Form in Africa: The Case of Eldoret City in Kenya, Paper presented at the Annual World Bank Conference on Land and Poverty 2015, "Linking Land Tenure and Use for Shared Prosperity," Washington, DC, March 23-27. Napier, M. 2013. Land and Markets in African Cities: Time for a New Lens? In Trading Places: Accessing Land in African Cities, ed. Mark Napier et al., 1-21. Cape Town: African Minds.

Olvera, L., D. Plat, and P. Pochet. 2003. Transportation Conditions and Access to Services in a Context of Urban Sprawl and Deregulation. The Case of Dar es Salaam. Transport Policy 10 (4): 287-298.

Palmer, Ian, and Stephen Berrisford. 2015. Final Report on Land-Based Financing for Urban Infrastructure in Sub-Saharan African Cities. Cape Town: African Centre for Cities.

Paulais, Thierry Tristan. 2012. Financing Africa's Cities: The Imperative of Local Investment, Africa Development Forum. Washington, DC: World Bank.

Payne, G., A. Piaskowy, and L. Kuritz. 2014. Land Tenure in Urban Environments, Issue Brief. Washington, DC: United States Agency for International Development (USAID).

Pejovich, S. 1990. The Economics of Property Rights: Towards a Theory of Comparative Systems. Dordrecht: Kluwer.

- 1995. Economic Analysis of Institutions and Systems. Dordrecht: Kluwer. Rakodi, C., and C.R. Leduka. 2004. Informal Land Delivery Processes and Access to Land for the Poor: A Comparative Study of Six African Cities, Policy Brief 6. University of Birmingham, International Development Department. 
Royston, L. 2013. Incrementally Securing Tenure: Promising Practices in Informal Settlement Upgrading in Southern Africa, Paper presented at the Annual World Bank Conference on Land and Poverty 2014, "Integrating Land Governance into the Post-2015 Agenda," Washington, DC, March 24-27.

Rurawanga, E. 2013. Land Tenure Reform. The Case Study of Rwanda, Paper presented at the Land Divided Conference 2013, "Land and South African Society in 2013, in Comparative Perspective," University of Cape Town, March 24-27.

Satterthwaite, D. 2009. Expanding the Supply and Reducing the Cost of Land for Housing in Urban Areas in Low- and Middle-Income Nations. Background Note. World Development Report: Reshaping Economic Geography. Washington, DC: World Bank.

Silva, C.M., ed. 2015. Urban Planning in Sub-Saharan Africa: Colonial and Postcolonial Planning Cultures. New York: Routledge.

Toulmin, C. 2008. Securing Land and Property Rights in Sub-Saharan Africa: The Role of Local Institutions. Land Use Policy 26: 10-19.

UN-Habitat. 2010. State of the World's Cities 2010/2011: Bridging the Urban Divide. Nairobi: United Nations Human Settlements Program.

. 2011. Ghana Housing Profile. Nairobi: United Nations Human Settlements Program.

. 2012a. Zambia Urban Housing Sector Profile. Nairobi: United Nations Human Settlements Program.

- 2012b. Handling Land: Innovative Tools for Land Governance and Secure Tenure. Nairobi: United Nations Human Settlements Program.

USAID (U.S. Agency for International Development). 2011. Cameroon Country Profile: Property Rights and Resource Governance. Washington, DC: USAID.

- 2013. Côte d'Ivoire Country Profile: Property Rights and Resource Governance. Washington, DC: USAID.

Wanjala, S.C. 1990. Land Law and Disputes in Kenya. Nairobi: Oxford University Press.

Weru, J. 2004. Community Federations and City Upgrading: The Work of Pamoja Trust and Muungano in Kenya. Environment and Urbanization 16 (1): 47-62.

World Bank. 2003. Land Policies for Growth and Poverty Reduction. New York: Oxford University Press and World Bank.

—. 2012. Doing Business 2012: Doing Business in a More Transparent World. Washington, DC: World Bank Group.

Size Enterprises. Washington, DC: World Bank Group. 
Open Access This chapter is licensed under the terms of the Creative Commons Attribution 4.0 International License (http://creativecommons.org/licenses/ by/4.0/), which permits use, sharing, adaptation, distribution and reproduction in any medium or format, as long as you give appropriate credit to the original author(s) and the source, provide a link to the Creative Commons license and indicate if changes were made.

The images or other third party material in this chapter are included in the chapter's Creative Commons license, unless indicated otherwise in a credit line to the material. If material is not included in the chapter's Creative Commons license and your intended use is not permitted by statutory regulation or exceeds the permitted use, you will need to obtain permission directly from the copyright holder.

(c) (i) 